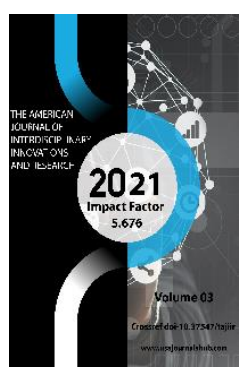

\title{
Theory And Structure Of Linguistic Competence
}

Jumanazarov U.U.

Doctor Of Philosophy In Pedagogical Sciences (PhD), Jizzakh State Pedagogical Institute, Uzbekistan

Copyright: Original

content from this work may be used under the terms of the creative commons attributes 4.0 licence.

\section{ABSTRACT}

The article summarizes the theory of linguistic competence to be formed and improved in future English teachers, the opinions, ideas and conclusions of scholars from the most developed countries in this regard. The structure of linguistic competence is defined, goals and objectives are defined.

\section{KEYWORDS}

linguistic competence, competence theory, competence, speaking ability, competence structure, goals and objectives, ability, skill, speaking activity, thinking, knowledge, skill.

\section{INTRODUCTION}

Linguistic competence, according to its structure, consists of speech (phonetic), lexical, phraseological and grammatical (morphological and syntactic) competencies, which was originally founded by Noom Chomsky. According to the theory put forward 
by this scientist, linguistic competence is the ability to understand words and sentences of a certain linguistic richness through an acoustic (phonetic) system, to distinguish grammatical sentences from words and sentences without grammatical rules; it is also a complex process competence that includes a system for performing other effective linguistic operations.

\section{THE MAIN FINDINGS AND RESULTS}

The theory of linguistic competence, introduced into scientific use by N. Chomsky, has revolutionized linguistics: it has caused a great deal of controversy in science [1, pp. 103122]. According to $S$. Thornbury, linguistic competence is the ability of language speakers to compose "newly formed sentences" [2]. system, we come across a number of ideas and conclusions that have emerged as a result of specific observations, specific observations of scientists from the most developed countries. We found it necessary to briefly record and comment on some of them.

In 1957, N. Chomsky referred to the scientific community the theory of generative grammar [3, pp. 35-59], which caused a wide discussion, defining it as a set of rules with a clear description of each sentence [4, pp. 99-194]. The tree-like diagram representing the structural description of the main scientific ideas proposed by the scientist in 1965 was as follows:

If we look briefly at the history of the theory of linguistic competence in the world education

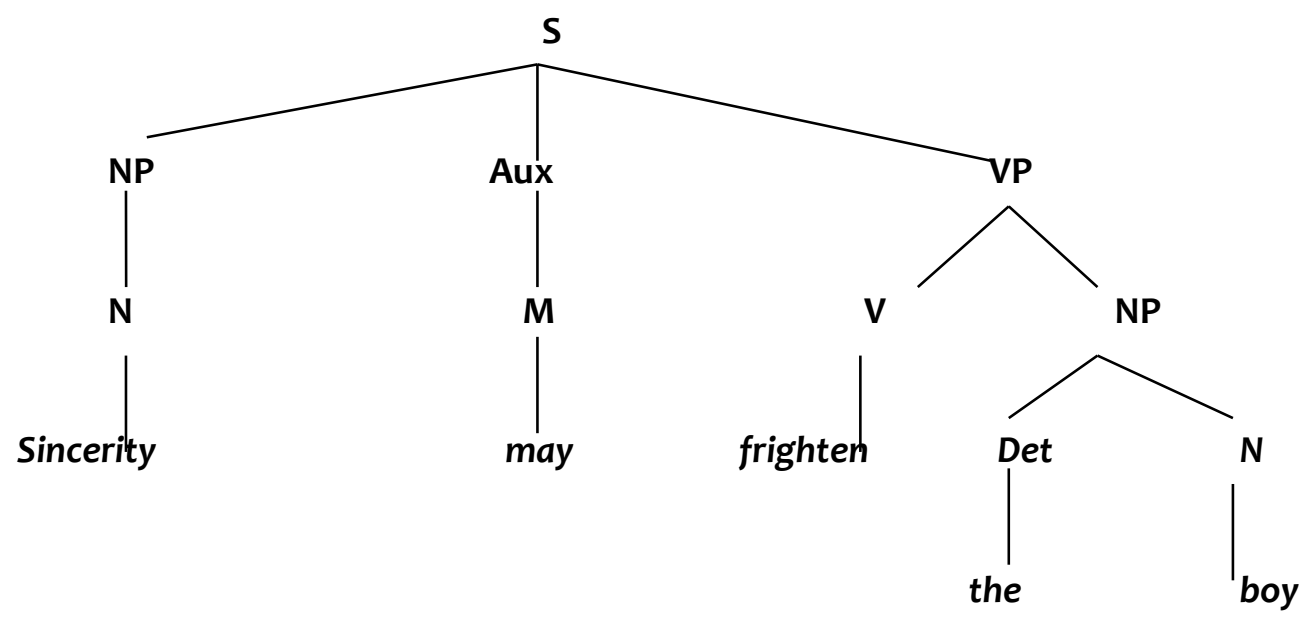

Figure 1

Taking into account the heated debates in the world scientific community, N. Chomsky introduced the concept of linguistic competence a few years later [4, pp. 99-194]. He argued that the "ideal speaker-listener" must have fully mastered the ability to speak the language he or she uses in his or her speech team, "a speaker of a particular language, everyone has mastered basic grammar", which indicates the extent of their knowledge [5].

N. Chomsky identified the differences between the concepts of competence (ability) and expression (speech). Competence is the practical application of an expression (speech) [6, pp. 1-47] if the speakers of the language 
(ideally the speaker-listener) know the linguistic system of their language, in particular the grammar [7]. However, the scientist emphasizes that a number of different factors need to be taken into account in order to study real linguistic activity. One of these factors is the qualification of native speakers, that is, the thorough acquisition of the competence of the mother tongue [5].

This scholar argues that the main goal of linguistic theory is to explain the mental processes based on the use of language, and therefore reminds that the goal of the study of linguistics should be the study of competence, not expression (speech) [1].

It is clear from this that this scholar paid special attention to linguistic competence, which allows language learners to create well-formed speech structures [10]. However, linguistic competence should not be considered the sole purpose of language learning: because the process of communication goes beyond the knowledge of creating well-structured sentences [2].

Given that this chapter of our research belongs to the purely theoretical aspect, here we will try to briefly comment on another important problem - the main ideas of scientific considerations in related fields related to the theory of linguistic competence.

In the scientific works of scientists of the most developed countries of the world, in particular, A.Priyanto, F.Heidari, S.A.Alavi and others, it was found that there is a moderate correlation between grammatical competence of students and oral communication (communicative) competencies [9, pp. 83-104]; also in the scientific works of Wahyuni D.Ihsan, D.R.Hayati it was found that there is a strong linguisticcommunicative connection between the linguistic (grammatical) competence and speech ability of the participants (speakers) [10, pp. 83-92]; In his research, Z.Akbari noted that grammar does not interfere with oral speech and does not hinder its activity [11, pp. 122-126].

In the work of D.A.Myhill, S.M.Jones, H.Lines, A.Watson, large-scale mixed methods have been studied [12, pp. 139-166]; Quantitative research of F. Karimkhani [13, pp. 1189-1196], S. Jones, D. Myhill, T. Bailey and others studied mixed methods [14, pp. 1241-1263]; In the experimental studies of P. Rajabi, E. Dezhkam, the potential advantages of teaching grammar in writing have been proven on the basis of convincing evidence [15, pp. 61-76]. However, it should be noted here that YH Huang's research on the theoretical model showed that there is no strong link between knowledge of grammar and their application in writing [16, pp. 500515].

Research by K. Mokhtari, H.B. Thompson, Z.Akbari, and others confirms that students 'knowledge of syntax is in many ways significantly related to their comprehension of what is being read [17, pp. 122-123]. C. Gascoigne's study explored aspects of form and grammatical rules, emphasis on spelling and punctuation, direct connection, and the activity of successfully filling in gaps that are not relevant to the text [18, pp.1-14]. However, A.L. Lopez concluded in his scientific work on correlation that grammatical competence alone is not sufficient to predict students 'comprehension skills; factors related to the learner - the text argued that the purpose of reading is the key to successful comprehension of the text being read [19, pp. 181-200]. D.A.Myhill, S.M. Jones, H.Lines, and A.Watson have found that the relationship between syntax knowledge and reading comprehension reflects the interrelated aspect of memory and language [20, pp. 136-166].

Quantitative research by Y.F. Liao has shown that lexical-grammatical knowledge is an important factor in the formation of $L 2$ hearing ability [21, pp. 37-116]; in his quantitative research, E. Oh proved that the ability to analyze a particular sentence is important in 
the formation of the ability to listen and understand the text read [22, pp. 257-285].

Research by mixed methods by scholars such as M.S. Effendi, U. Rokhyati, U.A. Rachman, A.D. Rakhmawati, D. Pertiwi has shown that students favored a deductive approach even though they demanded diversity [23, pp. 4246]; but in the comments of R.Andrews, C.Torgerson, S.Beverton, A.Freeman, T.Locke, G.Low, D.Zhu, it is recognized that teaching syntax has no effect on students' writing skills [24, pp. 39-55]; similarly, scholars such as S.Yoon, K.Hoshi, H.Zhao have proved that learners do not value passive learning of grammar [25, pp. 117-152].

According to A. Pazaver, H. Wang's qualitative and P. Saaristo's quantitative studies, all participants in the study confirmed that grammar is an important factor in language learning [26, pp. 279-318]; quantitative research by V.V. Tuan, on the other hand, has shown that students with linguistic competence tend to speak and write confidently on a particular topic [27, pp. 104122]. Research by T.S.Farrell, P.C.P.Lim, S.Phipps, S.Borg shows that teachers 'principles of teaching grammar do not always apply to their practice; showed that decisions and guidelines for teaching are related not only to their attitudes but also to other factors (such as time) [28, pp. 380-390].

The further continuation of such diverse opinions and brief interpretations concerning the theory of linguistic competence limits us in a certain sense. Given this situation, we have drawn attention to the definition of the structure and functions of linguistic competence, based on the goals set in this chapter of our work.

Linguistic competence refers to the types of speech (acoustic) activities in the practice of a foreign language, as well as phonetic, lexical, phraseological, grammatical (morphological and syntactic), stylistic knowledge from the independent levels of language. This competence includes the process of applying in everyday practice all the knowledge of listening, speaking, reading, writing and skills related to phonetics, vocabulary, phraseology, grammar through a variety of information about everyday life and the environment. The knowledge and skills acquired on the basis of these competencies can be the basis for students to use the English language independently in everyday practical situations, in special pedagogical activities. Therefore, all the knowledge and skills provided to students of the "English language" on the basis of the studied competencies, based on the curriculum, are aimed at developing their oral and written speech, and on this basis to improve their linguistic competencies.

\section{CONCLUSION}

To conclude, in the process of developing and improving the linguistic competencies of future English teachers, a number of extremely important goals and objectives are required. In our view, these tasks include:

1. It is recommended to activate the internal speech of students in the field and use it effectively in daily practice. The main goal is to ensure that the children of the nation can communicate in our native language at the required level, effectively and perfectly learn English, which is a language of specialization, and participate freely, fluently and actively in interethnic and intercultural dialogue.

2. To be able to communicate in English fluently and fluently only if the assigned task is successfully completed; as a future pedagogical specialist, to determine and understand the degree to which grammatical rules are expressed in the speech of English speakers, to be able to speak correctly structured linguistic sentences in pure English and to achieve free communicative communication; as a result, they form the basis for the 
development and improvement of linguistic competencies.

3. Development of the process of learning and communicating English in our country in today's globalization, increasing the number of hours of English language taught in educational institutions; the issues of establishing cooperation in English with foreign educators have risen to the level of public policy. Therefore, based on the objectives of teaching English at all stages of education, we consider it appropriate to increase the set of practical exercises for independent work on the types of speech activities and language units in the newly created textbooks. As a result, all the knowledge and skills acquired in the process of learning English in the field can be the basis for students to speak English fluently in practical situations and in interactions with foreign citizens, to use language units correctly in communication.

\section{REFERENCES}

1. Barman B. (2014). The Linguistic Philosophy of Noam Chomsky. Philosophy and Progress. 51(1-2). - pp. 103-122.

2. Thornbury S. (2006). An A-Z of ELT. Oxford: Macmillan Education.

3. Taha W.A. \& Reishaan A.K. (2008). The Relationship between Competence and Performance: Towards a Comprehensive TG Grammar. Adab al-kufa Journal, 1(2). pp. 35-59.

4. Tienson J. (1983). Linguistic Competence. Transactions of the Nebraska Academy of Sciences, XI. - pp. 99-194.

5. Chomsky N. (1965). Aspects of the Theory of Syntax. Cambridge, Massachusetts: The MIT Press.

6. Canale M. \& Swain M. (1980). Theoretical bases of communicative approaches to second language teaching and testing. Applied linguistics. 1(1). - pp. 1-47.
7. Chomsky N. (2006). Language and mind. 3rd ed. Cambridge: Cambridge University Press.

8. Jordan G. (2014). Theory construction in second language acquisition. Amsterdam and Philadelphia: John Benjamins.

9. Priyanto $A$. The Correlation Between English Grammar Competence and Speaking Fluency of Eleventh Grade Students in SMAN 1 Sidoarjo. RETAIN, 2013, 1(1), 1-6.; Heidari, F. \& Alavi, S. A. (2015). Knowledge of Grammar, Oral Communication Strategies, and oral Fluency: A Study of Iranian EFL Learners. Iranian Journal of Applied Language Studies. 7(1). - pp. 83-104.

10. Wahyuni D. Ihsan, D.R. Hayati. (2015). Linguistic Competence and Speaking Performance of English Education Study Program Students of Sriwijaya University. Journal of English Literacy Education. 1(2). - pp. 83-92.

11. Akbari Z. (2014). The role of grammar in second language reading comprehension: Iranian ESP context. Procedia-Social and Behavioral Sciences, 98. - pp. 122-126.

12. Myhill D.A., Jones, S.M., Lines H., Watson A. (2012). Re-thinking grammar: the impact of embedded grammar teaching on students' writing and students' metalinguistic understanding. Research Papers in Education. 27 (2). - pp. 139-166.

13. Karimkhani F. (2016). The relationship between EFL learners' writing performance with their grammar knowledge, writing strategy use and selfesteem. Advances in Asian Social Sciences (AASS), 7(2). - pp. 1189-1196.

14. Jones S., Myhill D., Bailey T. (2013). Grammar for writing? An investigation of the effects of contextualized grammar teaching on students' writing. Reading and Writing, 26(8). - pp. 1241-1263.

15. Rajabi P., Dezhkam E. The effect of explicit grammar instruction on improving writing accuracy of Iranian EFL learners. Journal of 
ELT and Applied Linguistics (JELTAL), 2014, 2(1). - pp. 61-76.

16. Huang Y.H. Does EFL Students' Grammatical Ability Account for Writing Ability? A Case Study. Chia Nan Annual Bulletin, 37, 2011. - pp. 500-515.

17. Mokhtari K., Thompson H.B. How problems of reading fluency and comprehension are related to difficulties in syntactic awareness skills among fifth graders. Literacy Research and Instruction, 2006, 46(1), 73-94; Akbari Z. The role of grammar in second language reading comprehension: Iranian ESP context. Procedia-Social and Behavioral Sciences, 98, 2014. - pp. 122-126.

18. Gascoigne C. (2005). Toward an understanding of the relationship between L2 reading comprehension and grammatical competence. The Reading Matrix, 5(2). - pp. 1-14.

19. López A.L. To what extent does grammar knowledge account for competence in $\mathrm{FL}$ reading comprehension in university students? RESLA, 21,2008. - pp. 181-200.

20. Myhill D.A., Jones S.M., Lines H., Watson A. (2012). Re-thinking grammar: the impact of embedded grammar teaching on students' writing and students' metalinguistic understanding. Research Papers in Education, 27 (2). - pp. 139-166.

21. Liao Y.F. (2007). Investigating the construct validity of the grammar and vocabulary section and the listening section of the ECCE: Lexico-grammatical ability as a predictor of $\mathrm{L} 2$ listening ability. Spaan fellow, 1001, 37. - pp. 37-116.

22. Oh E. (2016). Comparative studies on the roles of linguistic knowledge and sentence processing speed in L2 listening and reading comprehension in EFL tertiary sets. Reading Psychology, 37(2). - pp. 257-285.

23. Effendi M.S., Rokhyati U., Rachman U.A., Rakhmawati A.D., Pertiwi D. (2017). A Study on Grammar Teaching at an English Education Department in an EFL Context. International Journal on Studies in English
Language and Literature (IJSELL), 5 (1). pp. 42-46.

24. Andrews R., Torgerson C., Beverton S., Freeman A., LockeT., Low G., Zhu D. (2006). The effect of grammar teaching on writing development. British Educational Research Journal, 32(1). - pp. 39-55.

25. Yoon S., Hoshi K., Zhao H. (2004). The Evolution of Asian ESL Students' Perceptions of Grammar: Case Studies of 9 Learners. Carleton Papers in Applied Language Studies. - pp. 117-152.

26. Pazaver A., Wang H. (2009). Asian students' perceptions of grammar teaching in the ESL classroom. The International Journal of Language Society and Culture, 27. - pp. 27-35; Saaristo P. (2015). Grammar is the heart of language: Grammar and its role in language learning among Finnish University students. Voices of pedagogical development-expanding, enhancing and exploring higher education language learning. - pp. 279-318

27. Tuan V. V. (2009). Communicative Competence of the Fourth Year Students: Basis for Proposed English Language Program. English Language Teaching, 10(7). - pp. 104-122.

28. Farrell T.S., Lim P.C.P. (2005). Conceptions of Grammar Teaching: A Case Study of Teachers' Beliefs and Classroom Practices. TESL-EJ, 9(2). - pp. 1-13; Phipps S., Borg S. (2009). Exploring tensions between teachers' grammar teaching beliefs and practices. System, 37(3). - pp. 380-390. 